\title{
Influence of Climatic Phenomena on Sedimentation and Increase of Lake Enriquillo in Dominican Republic, 1900-2014
}

\author{
Rafael Mendez-Tejeda ${ }^{1} \&$ Ramon A. Delanoy ${ }^{2}$ \\ ${ }^{1}$ University of Puerto Rico in Carolina. Natural Science Dept.Lab. Atmospherical Science, Carolina, USA \\ ${ }^{2}$ Facultad de Ciencias, Instituto de Física, Universidad Autónoma de Santo Domingo, Santo Domingo, Dominican \\ Republic \\ Correspondence: Rafael Mendez-Tejeda, University of Puerto Rico in Carolina. Natural Science Dept.Lab. \\ Atmospherical Science, P.O. Box 4800. PR 00984, Carolina, USA. E-mail: rafael.mendez@upr.edu
}

Received: August 15, 2017

Accepted: August 29, 2017

Online Published: November 19, 2017

doi:10.5539/jgg.v9n4p19

URL: http://dx.doi.org/10.5539/jgg.v9n4p19

\begin{abstract}
From 2003 to 2013, Enriquillo Lake, Dominican Republic, showed an increase in water level of 13 meters, with its level changing from 42 to 29 meters below sea level (BSL). In 2003, its maximum depth was approximately 24 meters; in 2013, it was 37.1 meters. The water surface coverage increased from 194.9 to $391 \mathrm{~km}^{2}$, flooding agricultural areas and leaving hundreds of people homeless. In addition, salinity increased from $105 \%$ to $23.4 \%$, a decrease of 4.47 times comparable to the volume change, which increased 4.48 times according to topographic and bathymetric maps. These changes began with Tropical Storm Odette and occurred progressively through 15 additional tropical cyclones (TC) or hurricanes that struck Lake Enriquillo between 2003 and 2011. Other climatic phenomena that have great influence on the Caribbean climate include the following: North Atlantic Oscillation (NAO), Southern El Niño Oscillation (ENSO), the trade winds, North Atlantic Warm Pool, Multidecadal Oscillation, the anticyclone Caribbean Regulator Climate Centers (CRCCs), and the Bermuda-Azores High (Mendez-Tejeda et al. 2017). The sediment records deposited by the runoff from these phenomena were analyzed. These proxy records were used to determine the decadal fluctuations related to cyclonic systems and the resultant effect upon increasing the level of Lake Enriquillo (LE). The accumulation rate (TAS) was estimated by means of $210\left({ }^{210} \mathrm{~Pb}\right)$ lead radiochronology, elemental composition, and mineral and ignition loss. These results were correlated with the extreme climatic events that affected the Lake Enriquillo Basin (LEB) from 1900 and 2011.
\end{abstract}

Keywords: sedimentation, dating, Lead 210, Tropical Cyclone and flooding

\section{Introduction}

Enriquillo Lake is the largest, insular depression in the Caribbean region, located between latitudes 18.39-18.58 $\mathrm{N}$ and $71.49-71.84^{\circ} \mathrm{W}$ (Figure 1) in the southwestern part of the Dominican Republic (DR). It is bordered to the north by the Sierra de Neiba and to the south by the Sierra de Bahoruco. It is an endorheic lake, with a watershed of 3,048 $\mathrm{km}^{2}$, is hypersaline when its area is less than $300 \mathrm{~km}^{2}$ (Buck et al., 2005), and has maximum depth 68 (BLS). The lake possesses three islands: Cabrito, Barbarita, and the Islita (NASA, 2003).Some researchers (Benson and Paillet 1989, Carpenter et al., 2011, Comarazamy et al. 2015) used indicators of climate and environmental change. In this case, all the hydrological variables of the lake reflected change, including the volume of the lake, the surface, and the salinity (Buck et al., 2003). Among these changes, the most evident is the large amount of surface water, as it is observable by satellite. The most widely accepted hypothesis for the cause of changes in the lake surface is that there is a connection with natural climatic variations to geological time scales. The type of influence on climatic factors is supported by the literature (Mendez-Tejeda et al. 2016), wherein it discusses that any effect on the Caribbean climate would depend on several factors, such as the CRCC's, the NAO, the ENSO, trade winds, the Warm Water Pool North Atlantic, Multidecadal Oscillation, and the Azores anticyclone.

Recently, another study (Mahrokh et al., 2017) have raised the following question: why did the volumetric changes of the Lagos Azuei and Enriquillo presented different increases? From 2003 to 2013, Lake Enriquillo grew 88\%, while Lake Azuei only added $31 \%$ despite being relatively close to the other lake. It is these differences that raise new, research questions.

Due to the behavior of these CRCC's, there was a long dry period from 1982 to 2003; in 2003, lasting until the 
beginning of 2013, Lake Enriquillo began to increase its area every year, flooding agricultural and livestock areas. The floods were a cause of concern for the communities surrounding the lake and the Dominican Government. Mendez-Tejeda et al. (2016) analyzed the increases, determining that LE levels saw a rise of $17.2 \mathrm{~m}$ between 2000 and 2013. The impact generated by the unexplainable increase in the level of LE continued to mount for the population living in the LE area. Many conjectures arose to explain the phenomenon of a lake whose levels continued to increase, thus causing flooding, despite a lack of rainfall. While expectations increased with the 2010 earthquake in Haiti, there were no answers beyond those with little or no scientific basis to support the potential causes of the "unusual" lake growth. Some speculated that the earthquake had caused geological movements that allowed the entry of sea water from the Bay of Neiba. Others claimed that Lake Azuei, located at a higher elevation in Haiti, poured its waters through fissures caused by the earthquake; they argued that, as it is a region of low precipitations even in the wet season, these floods had to come from water originating from another region. Another important factor to consider is deforestation in the region played an extremely significant role in increasing runoff and sediment trawling (González et al., 2010; Romero-Luna \& Poteau 2011).

Several researchers, for example (Lane et al., 2017, Buck et al 2005, Mann et al 1984) have carried out important paleoclimatic investigations in the LE area, for example in Laguna Alejandro. The lagoon is located along the southeastern edge of the LEB and is separated from the Bahia de Neiba by a narrow (75-100-m wide) coastal barrier. They applied this technique to a recovered sediment core, which had already been analyzed for other sedimentary TC proxies. Negative $\delta^{18} \mathrm{O}$ anomalies identified in the ostracod valves in the stable isotope record are associated with TC deposits and are most easily explained by large influxes of 18O-depleted meteoric waters typical of intense tropical storms.

Some researchers (Mendez-Tejeda et al., 2017; Cocco, 2009; Comarazamy et al., 2015) concluded that the basin had not dropped enough water to produce the increases that the LE presented, determining that the water was coming from tributaries like the Cristobal Canal or some other source, while the Rio Yaque del Sur (the largest river in DR's southern region) was not considered to be a contributor to LE.

In an attempt to answer these questions, the following hypothesis is proposed: An analysis of the sediment deposits in Lake Enriquillo would determine the point of origin for other, unidentified water sources. With this hypothesis as a starting point, it was decided that a study of the sediments in LE, as well as Lake Azuei and the main lagoons that serve as tributaries (Laguna Cabral, Rincon Lagoon, Laguna de Limón, etc.) from 1900 to 2014 was necessary. In order to find the sediment origins of LE (which would serve as a fingerprint to identify the water sources) and its relationship to the tropical systems that have impacted the region from 1900 to 2014, data and samples were collected from sediments in LE from 2003-2011.

\section{Study Area}

The Enriquillo Valley (Fig. 1) is located in the southwestern Dominican Republic. The main cities located around LE are: Jimani, La Descubierta, Neiba, Postrer Río, Duvergé, Boca de Cachón, Mella, Villa Jaragua, Los Ríos, El Limón, and Galván. These towns belong to the provinces Independencia and Bahoruco, with 54,785 and 97,313 inhabitants, respectively. Agriculture and livestock are the primary economic activities (National Bureau of Statistics, RD, 2010). The region is home to the Holocene coral reefs, a wonder of preservation in today's world. The unique exposure and preservation of Enriquillo carbonates makes this an excellent location to explore, via proxy data, mid-Holocene climate change, as shown in Figure 2 (Greer et al., 2006)

The hydrology of the modern Enriquillo Valley is complicated by baseline hypsography and tectonism in the Caribbean region (Mann et al., 1984; Medley et al., 2007; Cuevas et al., 2005). The flora originates from dry forest, which is much dispersed. The fauna is characterized mainly by reptiles, including iguanas (Cyclura cornuta and Cyclura ricordi) and crocodiles (Crocodylidae), and several types of birds, including flamingos (Phoenicopterus ruber), several species of herons (Ardeidae), and gulls (Laridae) (Marcano, 1987). The LE basin has several tributary sub-basins: Guayabal, Los Bolos, Penitente, Damas, Boca de Cachón, La Azufrada, La Zurza, Angostura, Barmesí, Panzo River, Barreno River, Río Blanco or Solié River, Penitente River, Lagoon of Rincon, Laguna de Limón, part of the Yaque del Sur basin through the Cristóbal canal (including the waters served by the water region's aqueducts from other basins), the Las Barias and Las Marías springs, and more than 700 other, small springs (Cocco, 2009). It is the second driest region in the DR. Hydrodynamics is defined by evaporation, May/December rains, troughs, storms, and hurricanes impacting the basin during the cyclonic season during JuneNovember (Delanoy et al., 2017; Rosado et al., 2016). 


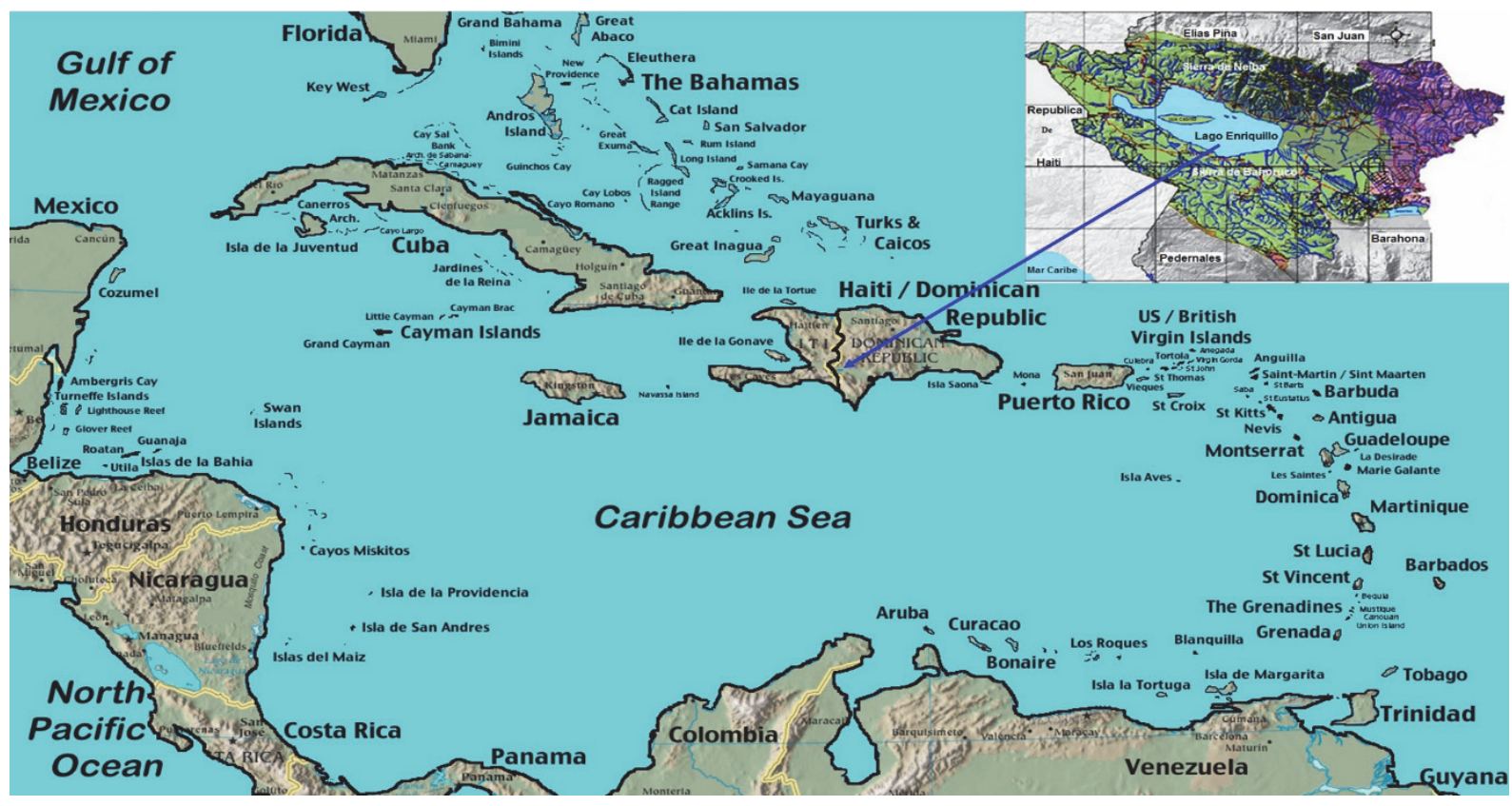

Figure 1. Map of the Caribbean region and location the Lake Enriquillo Basin Between latitudes 18.39-18.58 $\mathrm{N}$ and $71.49-71.84^{\circ} \mathrm{W}$ in the Dominican Republic

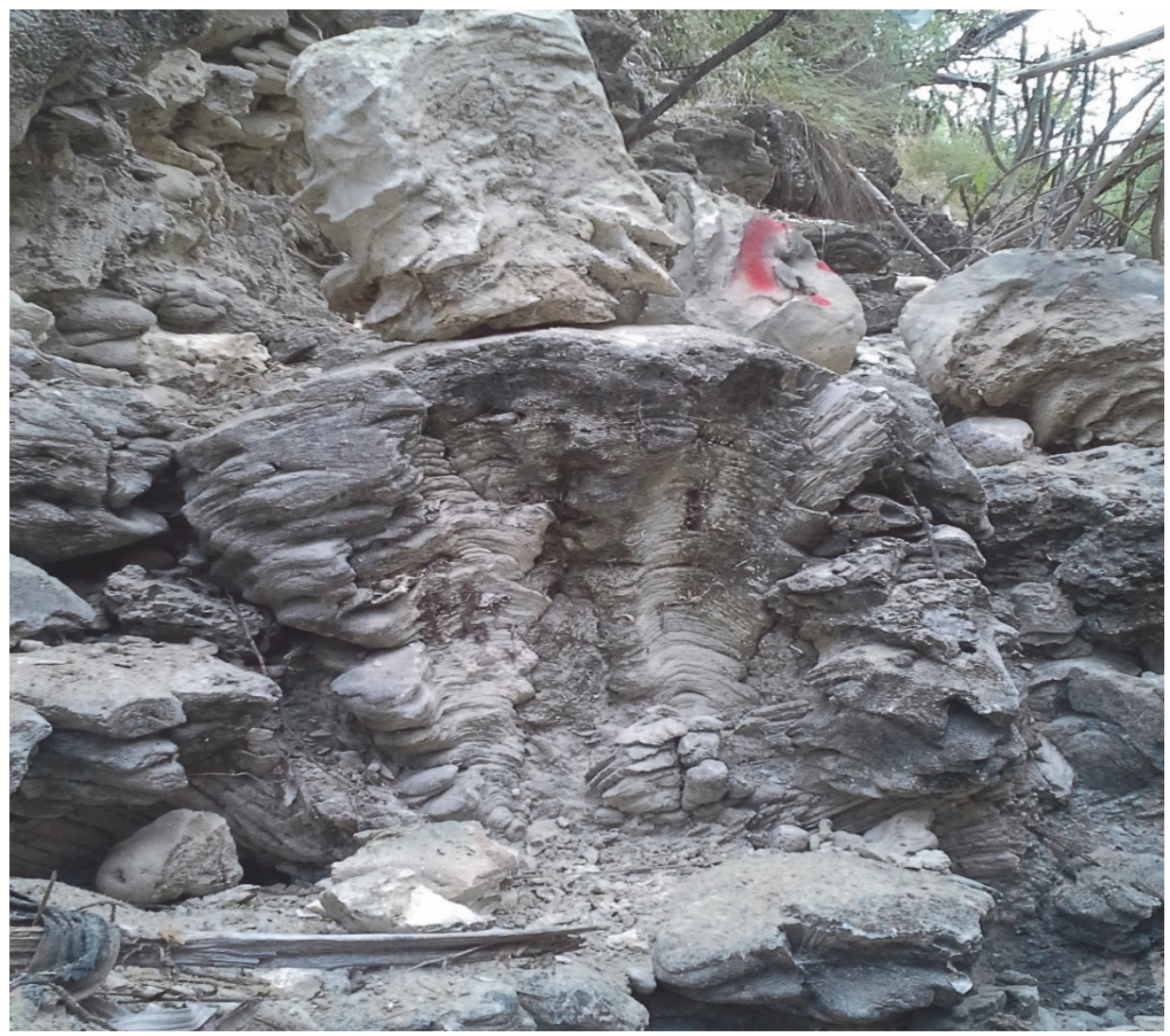

Figure 2. The excellent exposure and preservation of Holocene corals and related sediments allows for high resolution, proxy paleoenvironmental and paleoclimate analyses. Photo by Méndez-Tejeda, 2015 


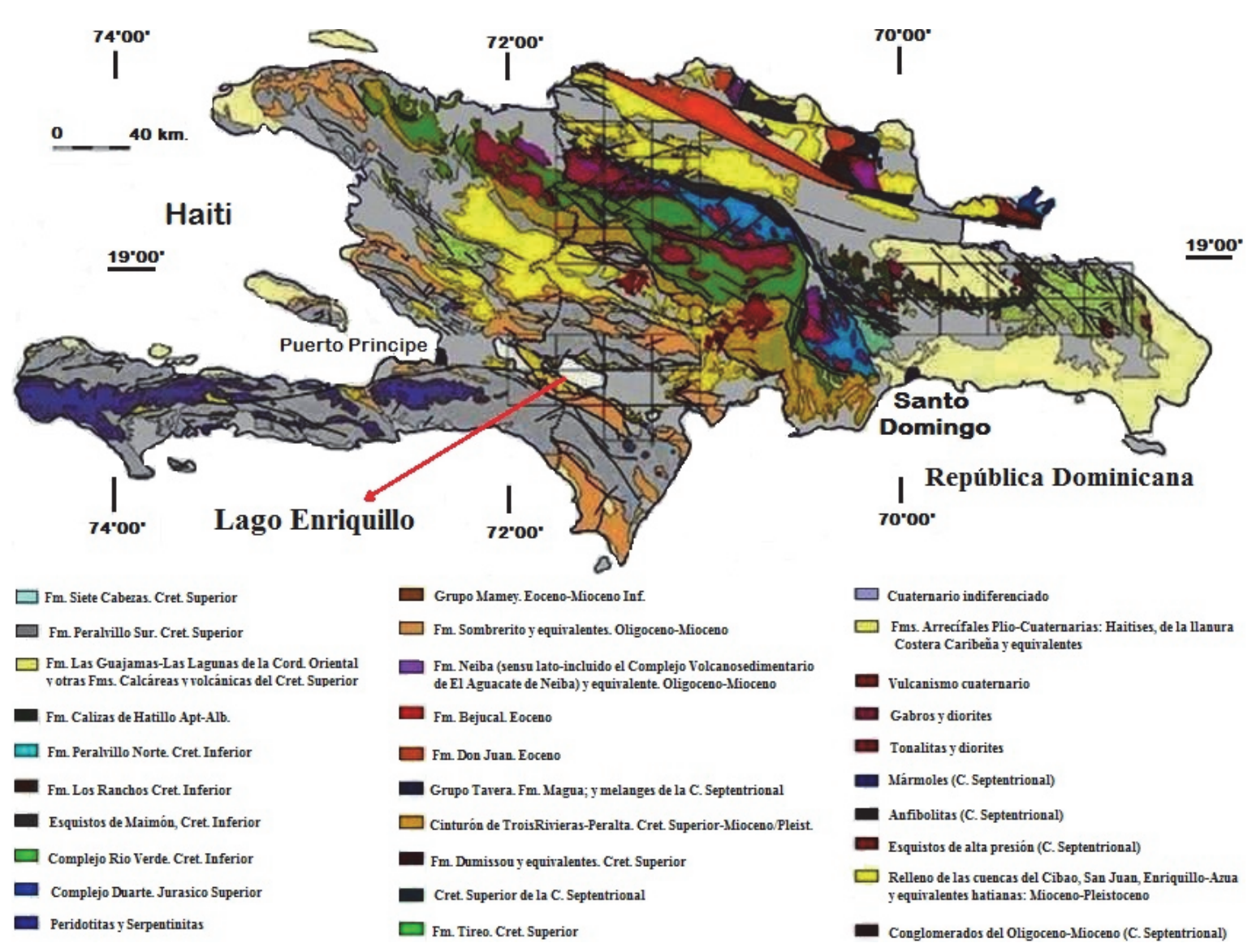

Figure 3. Geological Map of the Island of Santo Domingo, Dominican Geological Survey. The EnriquilloPlantain Garden fault, where the 2010 Haiti Earthquake was generated (Bird, 1980), runs south of Lake Enriquillo on its way toward Haiti. It is the main geological fault in the region (Bionini et al., 1984; Mann et al., 1984)

\section{Geology}

Lake Enriquillo is bordered by the Sierra de Neiba to the north and by the Bohoruco to the south, formed in the Eocene a part of the Tertiary era in the late Cenozoic era; These are composed of limestone rocks of marine origin, rich in calcium carbonate due to their calcareous origin, including the remains of mollusks, crustaceans, and coral from their time in the bottom of the sea during the Holocene (Mann et al., 1984). The rocks are highly fractured due to tectonism in the region (Bowin, 1966; Dolan et al., 1991). There are a series of basic geological faults (Trefethen, 1981) and no formations (Heubeck et al., 1991). The most prominent faults are the Enriquillo-Plantain Garden and the Neiba, which delineate the Enriquillo Basin (Mann et al., 1999) (Figure 3). There was an earthquake on the Enriquillo-Plantain Garden fault measuring 7.0 Richter magnitude (USGS, 2010), with an epicenter located in Port-au-Prince, Haiti. During the early Miocene, a large amount of sediment from the Sierras de Neiba and Bahoruco was washed away by the rivers, canyons, and streams, as well as by the torrential rains that accompanied storms and hurricanes (Stemann \& Johnson, 1992). The deposits of lake sediment reached a thickness greater than 500 meters (Wallace, 1947), which trapped a reservoir of water to the east, now named Enriquillo lake and to the west, now called Lake Azuei (Mann, 1991; Diaz and Solé, 2002). The sediments linked to tectonics and closed the channel connection, separating the Neiba and Bahoruco ranges and forming the Bay of Port-au-Prince (Van den Berghe, 1983; Pubellier, 2000). On the shores of Lake Enriquillo, partially-intact corals of Holocene origin were deposited, buried by sediment (Stemann and Johnson, 1992), as along with deposits of mollusk shells (Radke et al., 2003) and the remains of a variety of crustaceans (Mann et al., 1984; Mann et al., 1999). In the Discovery range, these elements are mixed with fragments of dolomite, calcite, and other rocks composed primarily of calcium carbonate, sometimes substituted by strontium (Hernaiz Huerta, 2004).

\section{Methodology}

Using radioisotope nuclear analytical techniques, such as lead dating 210 , an evaluation of sediment deposits from 
100 years ago could be conducted. This would include analysis of sedimentary colors as natural records, sedimentation processes, and their correspondence with hydro-meteorological events like storms and hurricanes that have frequently impacted the region for several millennia. Using an Uwitec sampler, 20 sedimentary profiles were collected at Lake Enriquillo in centimeter sections. The 20 profiles, or cores, were tested for moisture,

Ignition, inorganic carbon (Ahumada, 1991), and elemental composition were analyzed. After a portion of sediment from each section was consumed to perform dating identification and to determine the Sedimentary Accumulation Rate (SAR) and the Mass Accumulation Rate (MAR), Lead $210\left({ }^{210} \mathrm{~Pb}\right)$ was found in nine cores. Assuming Constant Flow (FC) where the age of each layer is determined by the expression:

$$
t(i)=\frac{1}{\lambda} \ln \frac{A(0)}{A(i)}
$$

Where $\lambda$ is the constant of Half-life of ${ }^{210} \mathrm{~Pb}, \mathrm{~A}(0)$ activity of the upper layer and A (i) activity of each layer (Appleby and Oldfield, 1978). While the TAM is given by:

$$
r_{i}=\frac{\lambda(A(i))}{C i}\left(\mathrm{grcm}^{-2} y^{-1}\right)
$$

Where Sedimentary Accumulation Rate (TAS) is giving by

$$
S i=\left(\frac{r_{i}}{\rho_{i}}\right) x 100\left(c m y^{-1}\right)
$$

Where $\mathrm{Ci}$ is the accumulated activity per unit mass deposited annually per square centimeter and $\rho$ i the sediment density (Sánchez-Cabeza et al., 2012; Mosqueda et al., 2010)

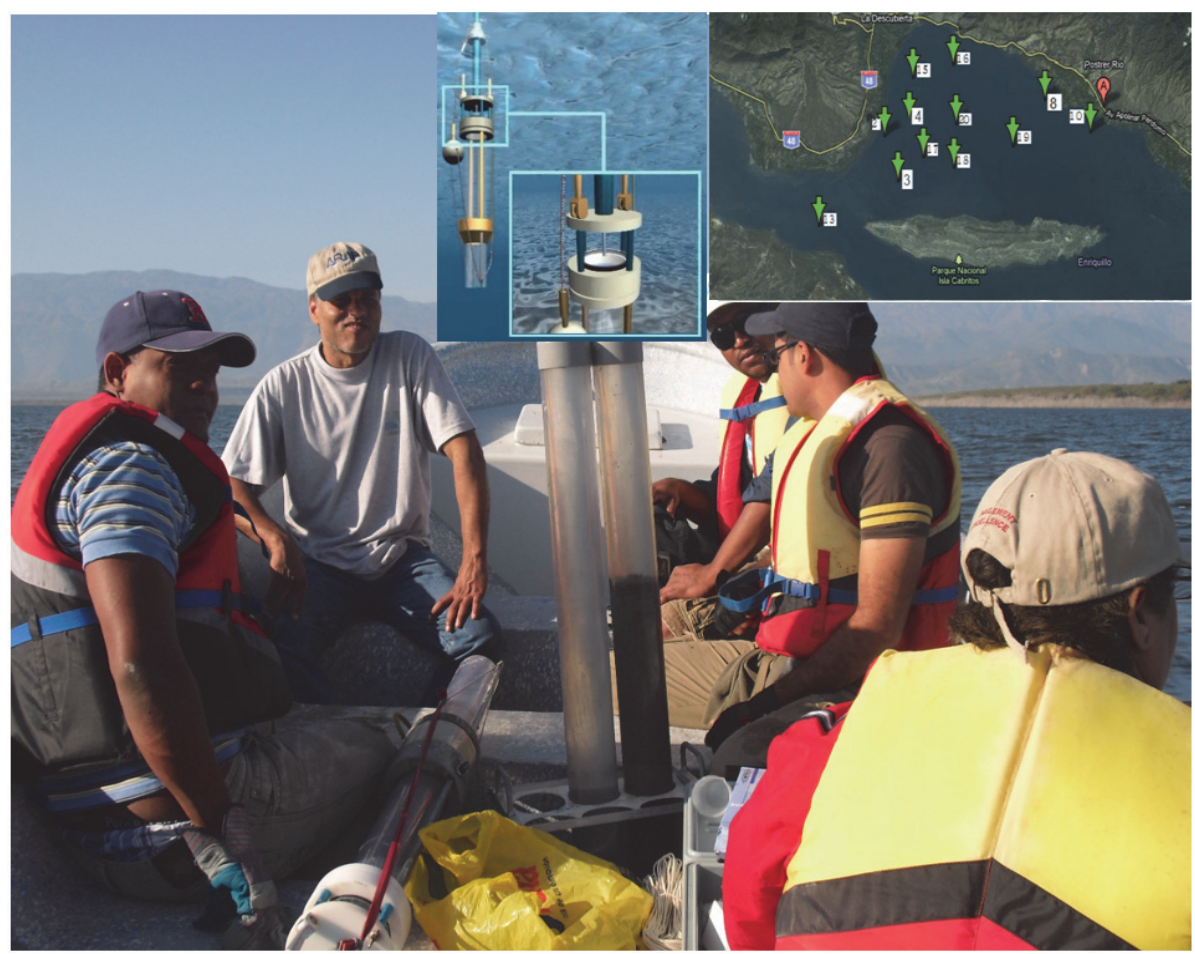

Figure 4. Sampling campaign with Uwitec sampler (horizontal position). The lengths of the tubes are 1.20 meters, the core is number 2 with a length of more than $80 \mathrm{~cm}$ corresponded to the zone influenced by the Los Pinos river near La Descubierta (latitude 18.5261 North and longitude 71.7311 West with a TAS $=2.55 \mathrm{~cm}$ a-1 (2003-2011) core number $10(67 \mathrm{~cm})$ influenced by the Guayabal River to the north, number 13 by the waters coming from Jimani and Boca de Cachón

\section{Results}

Table 1. The Surface Covered by LE 1982-2010 (USGS 2010; NOAA 2014). *The areas from 2011-2013 were calculated during the development of the study, with a $0.8 \%$ error using Google Earth, Okimap, and Surfer 11. The 
volumes according to the bathymetry and topography of Lake Enriquillo determined in 1992 (Araguás-Araguás et al., 1993) and 2013 (Delanoy, 2013).

\begin{tabular}{|c|c|c|c|c|c|}
\hline Date & YearArea $\left(\mathbf{k m}^{2}\right)$ & )Date & $\begin{array}{l}\text { Pearitio } \\
\text { (BSL) }\end{array}$ & $\begin{array}{l}\text { QVolum } \\
\left(\mathbf{k m}^{3}\right)\end{array}$ & $\begin{array}{c}\text { eArea } \\
\left(\mathrm{km}^{2}\right)\end{array}$ Tropical Cyclone \\
\hline \multirow{2}{*}{ 17-Jan-82 } & 21982291.6 & 10-Jul-96 & 1996 & & 225.5 \\
\hline & 1983 & 27-Jun-97 & 1997 & & 212.5 \\
\hline 23-Jan-84 & +1984285.1 & 30-Jun-98 & 1998 & & 197.9 \\
\hline $2-F e b-85$ & 1985271.7 & 1-Jun-99 & 1999 & & 231.2 H. George \\
\hline 20-Jan-86 & 51986268.4 & 6-Aug-00 & 2000 & & 232.4 \\
\hline 23-Jan-87 & 71987268.3 & 9-Jan-01 & 2001 & & 233.0 \\
\hline 1-Nov-88 & 1988262.9 & 9-Feb-02 & 2002 & & 212.3 \\
\hline 4-Jan-89 & 1989262.8 & 2-Feb-03 & 200342.0 & 1.14 & 194.9 T. Odette \\
\hline \multirow[t]{2}{*}{ 31-Jan-90 } & 1990259.7 & 30-Jan-04 & 200441.5 & & 198.6 H. Jeanne \\
\hline & 1991 & 16-Jan-05 & 200541.0 & & 202.5 T. Alpha \\
\hline \multirow[t]{8}{*}{ 22-Feb-92 } & 21992238.2 & 3-Jan-06 & 200640.5 & 1.86 & 236.4 \\
\hline & 1993 & 22-Jan-07 & 200740.0 & 2.03 & 255.9 T. Noel-Olga \\
\hline & 1994 & 9-Jan-08 & 200836.0 & 3.67 & $\begin{array}{l}\text { 303.2 T. Fay, Gustav- } \\
\text { Hanna-Ike }\end{array}$ \\
\hline & 1995 & 11-Jan-09 & 200934.0 & 3.89 & 331.6 \\
\hline & & 22-Jan-10 & 201033.0 & 4.22 & 332.3 T. Tomas \\
\hline & & 29-Feb-11 & 201130.0 & $4.60^{*}$ & 375.4 T. Emily \\
\hline & & 28-Feb-11 & 201229.5 & $4.99 *$ & 385.3 T. Ernesto, Isaac y Sandy \\
\hline & & 23-May-13 & 3201329.0 & $5.22 *$ & 391.4 T. Chantal \\
\hline
\end{tabular}

Table 2. Measures of Salinity, Conductivity and Total Dissolved Solids during the period 2011-2014 at Lake Enriquillo. The values presented are average values. * (Margalef, 1985; Buck, 2005). Conductivity $=1.36$ * Salinity $+5.13, \mathrm{R}^{2}=0.99$; Total Solids Dissolved $=1.66 *$ Salinity-21.19, $\mathrm{R}^{2}=0.95$ Equations constructed from the measured data.

\begin{tabular}{lrrr}
\hline \multicolumn{1}{c}{ Date } & $\begin{array}{c}\text { Salinity } \\
(\mathbf{\% o})\end{array}$ & Conductivity (mS/cm) & Total dissolved solids (\%) \\
\hline *Nov. 2002 & 104.2 & 146.8 & 152.1 \\
*Mar. 2003 & 103.4 & 145.9 & 150.7 \\
28 de Feb. 2011 & 30.4 & 46.5 & 30.1 \\
28 de Feb. 2012 & 26.1 & 40.6 & 20.3 \\
13 de May 2013 & 23.7 & 37.6 & 18.8 \\
16 de Dec. 2013 & 24.4 & 38.3 & 19.2 \\
23 de May 2014 & 23.4 & 36.8 & 18.5 \\
\hline
\end{tabular}

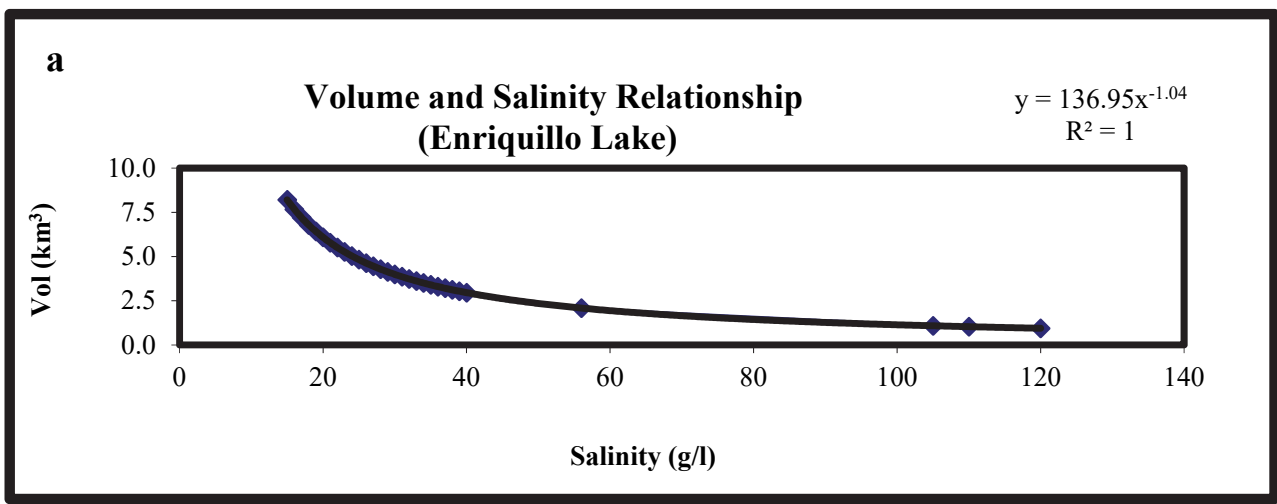




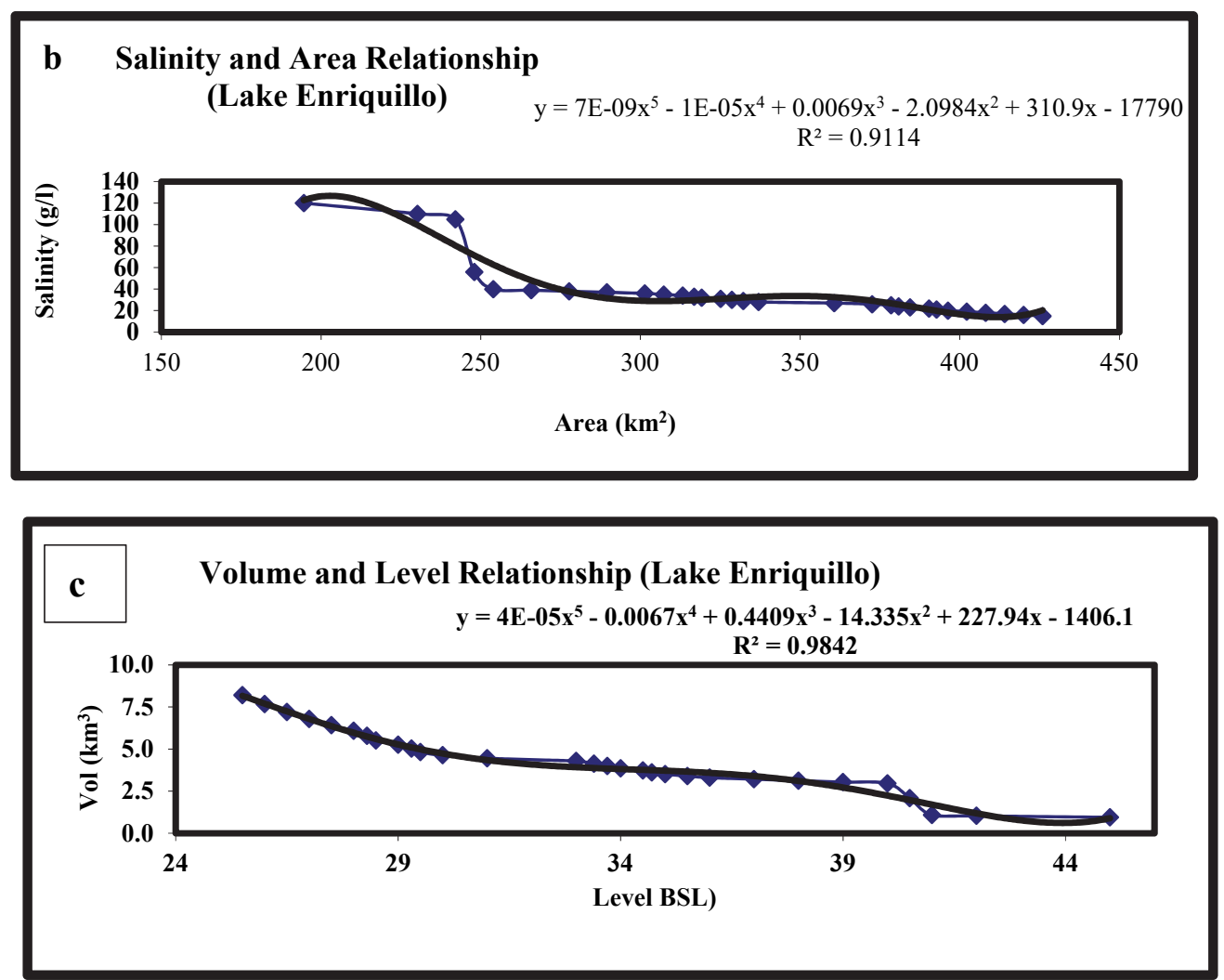

Figure 5. (a) The volume and level maintain a close to linear relationship, except between -42 and $-40 \mathrm{~m}$ (BSL). Due to bathymetry and topography of the basin, the fifth-order polynomial is the one that best relates to volume and level. (b) Salinity shows a sharp change for the same reason. From $240 \mathrm{~km}^{2}$ there is a sudden change in salinity which is smoothed from $250 \mathrm{~km}^{2}$ related to the abrupt change in volume. The polynomial of order five of the trend curve is the one that best relates to the variables. (c) There is a relationship between the salinity and the volume related to the equation presented in the graph. The water features of Lake Enriquillo are unique in that they vary in relation to sea water or other lakes. Evaporation is considered as another influence that could alter the hydrodynamics of the lake. The empirical equation is as follows: $\mathrm{E}=75 * \mathrm{~T}$, where $\mathrm{T}$ is the annual mean lake temperature $\left(27^{\circ} \mathrm{C}\right)$ and $\mathrm{E}$ is given in $\mathrm{mm}$

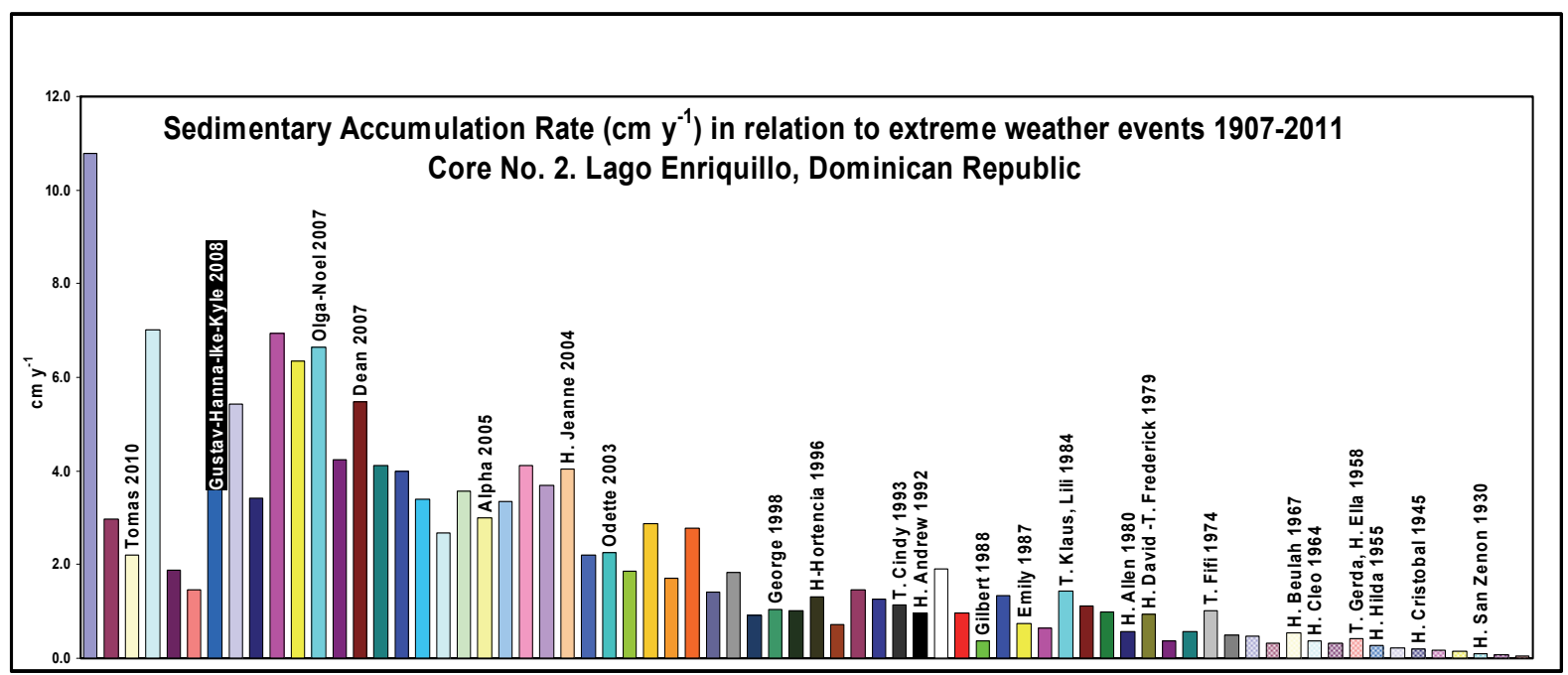

Figure 6a (Core no. 2): It was observed that, during and after the passage of a TC, the rate of accumulation increases. From 1979-1998, the levels remained below $1.6 \mathrm{~cm}$ y-1, defined as a drought period in the basin 
Sedimentary Accumulation Rate $\left(\mathrm{cm} \mathrm{y}^{-1}\right)$ in relation to extreme weather events 1900-2011, Core No. 10. Lago Enriquillo, Dominican Republic

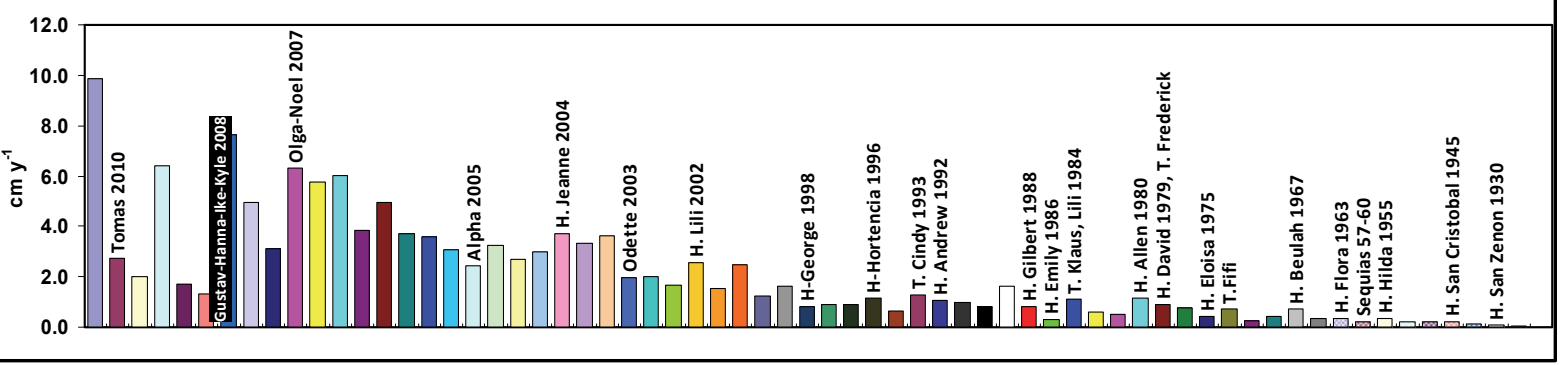

Figure 6b. From 2003-2011, the sedimentary accumulation rate (SAR) reached $2.45 \mathrm{~cm} \mathrm{y}^{-1}$ near the mouth of the Guayabal river (core no. 10); the Los Pinos la Descubierta rate approached $2.55 \mathrm{~cm} \mathrm{y}^{-1}$. The same characteristics were observed in other cores from different depths, the variation in the sedimentation rate occurring in accordance with the influence of the incident aquifers
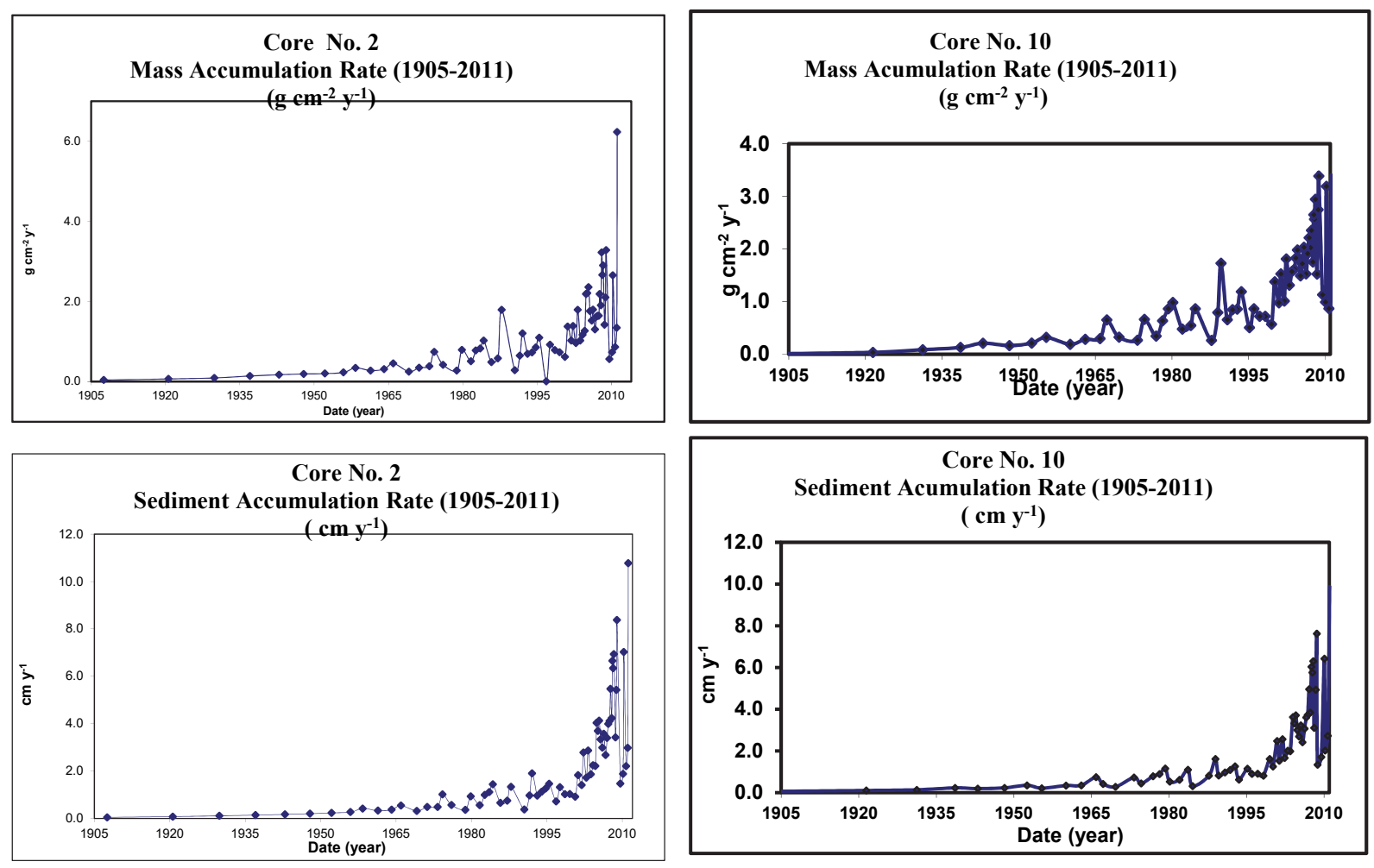

Figure 7. Comparison of the mass and sedimentary accumulation rate of core No. 2 (taken from the south of the discovery reservoir from sediments in the Los Pinos River) with No. 10 (influenced by the sediments coming from the Guayabal River). The charts show that the SAR and the MAR began to increase in 1965, just after the passage of Hurricane Flora in 1963. Between 1979-1998, SAR and MAR oscillate between 0.32 and $1.6 \mathrm{~cm}$ y-1 for core no. 10 and from 0.56 to $1.9 \mathrm{~cm} \mathrm{y}-1$ for core no. 2 , indicating an increased rate of sedimentation in that region 

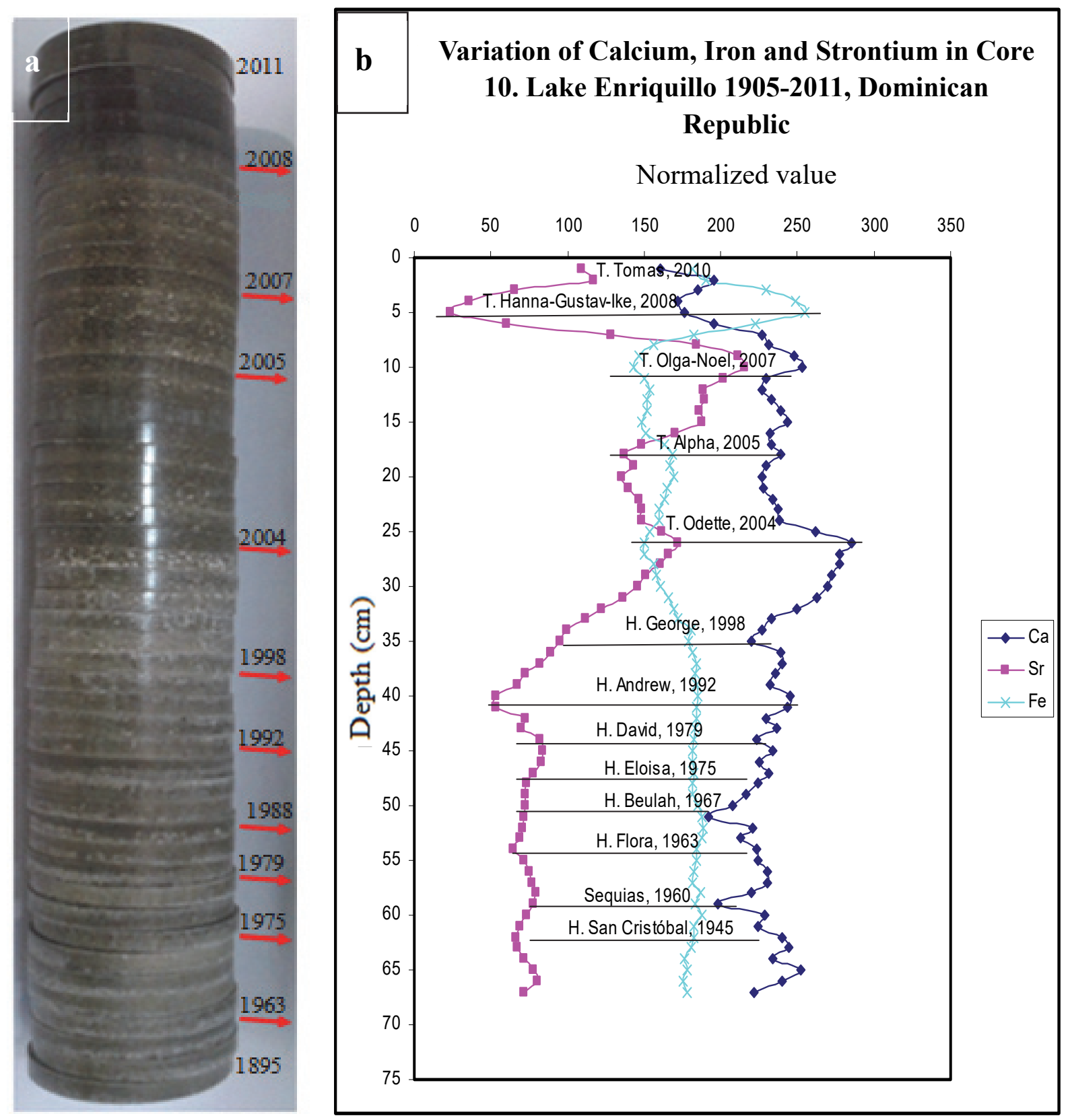

Figure 8. (a) The pads, when placed on top of each other from the surface up to $67 \mathrm{~cm}$, correspond to each sediment section of Profile Num. 10. For the preparation of each tablet, three grams of dry sediment were taken and subjected to a force of 20 tons confined to an area of $4.9 \mathrm{~cm}^{2}$. The marked years, determined by ${ }^{210} \mathrm{~Pb}$, indicate changes in the sedimentation regime and correspond to extreme meteorological phenomena. The color change is observed. (b) Variations of calcium, iron and strontium indicate a change in the sedimentation regime associated with extreme climatic events (normalized values with calcium). Elemental data was obtained by fluorescence X-rays. The main element is calcium and the basin is formed of karst rocks. A period of drought began in 1982, three years after Hurricane David and Storm Frederick struck the region, and continued until 2003, when the storm Odette struck. This drought experienced a minor interruption from Hurricane Andrew (1992). The arrival of Odette initiated an increase of lake levels from 2003-2013. By the end of that decade, it began to descend with the onset of another drought. Studies confirmed that effects from the passage of a storm or hurricane took between two and three years to finish arriving at the lake. This explained why Lake Enriquillo continued to receive an "unusual" volume of water more than two years after a hurricane or storm passed through 
Table 3. Variation of the SAR and the MAR before and after the occurrence of extreme weather events in the Lake Enriquillo basin, determined from ${ }^{210} \mathrm{~Pb}$. The length of profile No. 10 was 67 centimeters. The level increase started at $24.5 \mathrm{~cm}$ (T. Odette, 2003), for a SAR $=3.4 \mathrm{~cm}$ y-1 and MAR $=1.8 \mathrm{~g} \mathrm{~cm}^{2}$ a-1 average (2003-2011). After the passage of Hurricane Andrew in 1992, the lake's level diminished until 2003, when its progressive increase began and lasted until 2013, when it again experienced a decrease in its level. Similar occurrences occurred after the passage of Hurricane Beulah in 1967 until the passage of Hurricane David and Storm Federico in 1979

\begin{tabular}{|c|c|c|c|c|c|c|c|}
\hline \multirow{2}{*}{$\begin{array}{l}\text { Depth } \\
\mathrm{z}(\mathrm{i}) \\
(\mathrm{cm})\end{array}$} & \multirow{2}{*}{$\begin{array}{l}\text { Age } \\
\text { t(i) } \\
\text { (yr) }\end{array}$} & \multicolumn{3}{|c|}{ Mass Accumulation Rate (MAR) } & \multicolumn{2}{|c|}{$\begin{array}{l}\text { Sedimentary Accumulation } \\
\text { Rate (SAR) }\end{array}$} & \multirow{2}{*}{ Tropical Cyclone } \\
\hline & & Date & $\begin{array}{l}\mathrm{r}_{\mathrm{i}} \text { Before } \\
\left(\mathrm{g} \mathrm{cm}^{-2} \mathrm{a}^{-1}\right)\end{array}$ & $\begin{array}{ll}r_{i} & \text { After } \\
\left(\mathrm{g} \mathrm{cm}^{-2} \mathrm{a}^{-1}\right)\end{array}$ & $\begin{array}{l}\text { si Before } \\
\left(\mathrm{cm} \mathrm{y}^{-1}\right)\end{array}$ & $\begin{array}{l}\text { si After } \\
\left(\mathrm{cm} \mathrm{y}^{-1}\right)\end{array}$ & \\
\hline 1.5 & 0.10 & 2011.1 & 0.87 & 0.96 & 2.02 & 2.73 & Tomas 2010 \\
\hline 6.5 & 2.45 & 2008.7 & 2.75 & 3.39 & 4.93 & 7.62 & $\begin{array}{l}\text { Gustav-Hanna-Ike-Kyle } \\
2008\end{array}$ \\
\hline 9.5 & 3.11 & 2008.1 & 2.57 & 2.94 & 5.76 & 6.30 & Olga-Noel 2007 \\
\hline 17.5 & 4.94 & 2006.2 & 1.53 & 1.91 & 2.42 & 3.07 & Alpha 2005 \\
\hline 21.5 & 6.36 & 2004.8 & 1.83 & 1.98 & 3.32 & 3.71 & H. Jeanne 2004 \\
\hline 24.5 & 7.21 & 2004.0 & 1.31 & 1.61 & 1.98 & 1.67 & Odette 2003 \\
\hline 31.5 & 11.06 & 2000.1 & 1.38 & 0.57 & 1.62 & 0.81 & H-George 1998 \\
\hline 35.5 & 15.14 & 1996.0 & 0.51 & 0.86 & 0.62 & 1.15 & H-Hortencia 1996 \\
\hline 38.5 & 18.41 & 1992.8 & 0.85 & 0.86 & 0.97 & 1.09 & H. Andrew 1992 \\
\hline 48.5 & 31.88 & 1979.3 & 0.64 & 0.87 & 0.79 & 0.89 & $\begin{array}{l}\text { H. David 1979, T. } \\
\text { Frederic }\end{array}$ \\
\hline 51.5 & 36.56 & 1974.6 & 0.27 & 0.66 & 0.28 & 0.72 & T. Fifi \\
\hline 54.5 & 43.93 & 1967.2 & 0.30 & 0.65 & 0.35 & 0.74 & H. Beulah 1967 \\
\hline 56.5 & 48.14 & 1963.0 & 0.19 & 0.28 & 0.21 & 0.34 & H. Flora 1963 \\
\hline 57.5 & 51.09 & 1960.1 & 0.32 & 0.21 & 0.35 & 0.21 & Sequias $57-60$ \\
\hline 61.5 & 68.17 & 1943.0 & 0.13 & 0.21 & 0.14 & 0.23 & H. San Cristobal 1945 \\
\hline 63.5 & 79.95 & 1931.2 & 0.03 & 0.09 & 0.04 & 0.10 & H. San Zenon 1930 \\
\hline
\end{tabular}

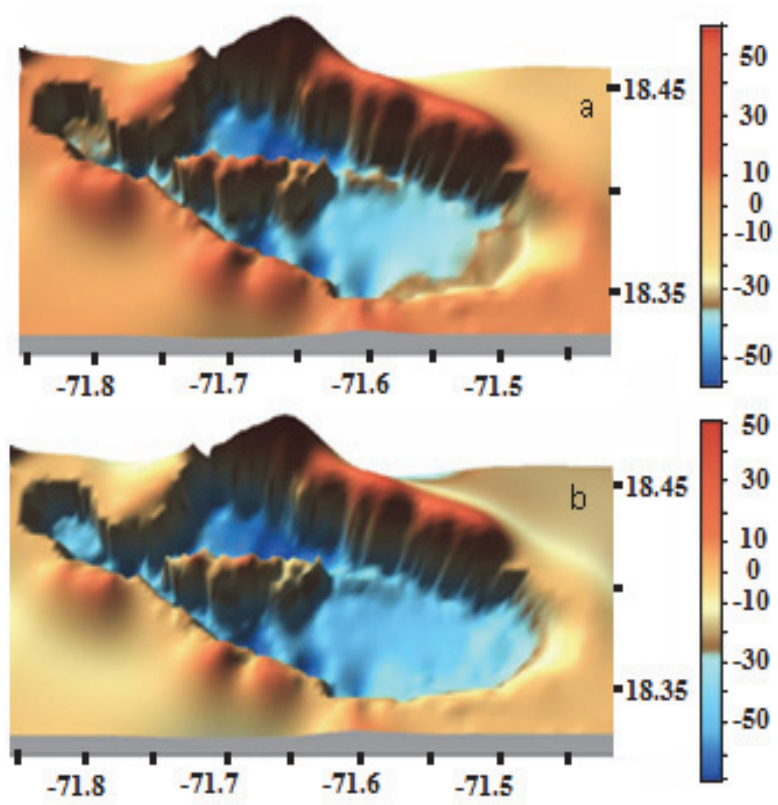

Figure 9. Bathymetric map of Lake Enriquillo. (A) level -42 BSL (2003). (B) level -29 BSL (2013). The Barbarita Islands and the Islita Islands in 2013 were covered by water. Cabrito Island lost more than $12 \mathrm{~km}^{2}$ of its surface. The surface area of occupation of the waters had extended from 194.9 to $391.4 \mathrm{~km}^{2}$. The bottom of the lake is very irregular, with characteristic of reefs zones, with uniform gaps sloping as if they were a "pot".

The maximum depth (68.1 BSL) is in the northern part, closer to Cabrito Island than the northern shore. 


\section{Characterization of Sediments}

The loss of moisture, by ignition and calcination of profile Num. 10 (Figure 5) taken from the north section of Lake Enriquillo, shows that the moisture and organic matter (Páez-Osuna et al. 1984) contained a trend that lent itself to the accomplishment of dating; the same was present in the profiles $2,8,13,16,17,18,19$, and 20 . The organic matter (MO) contained in the sediments oscillates between 13 and $35 \%$, observing several peaks in the MO content (Meyers and Ishiwatari, 1993) and in the TAS (Table 4). On the surface and inside the sediments, remains of agricultural plants were found which are typical of the flora of the undeveloped area (La Descubierta, Jimaní, Postrer Ríos and Neiba). Variation in color occurred when burned along with the emission of a characteristic odor (Révész et al., 2012; Palacios et al., 2012). One big number of shells and the depths to which they are found (Hernández, 2001). Three distinct layers appeared in the cores (Figure 8b), with three marked periods in the changes in sedimentation regime (Ruiz-Fernández et al., 2004). The first layer reached 40 centimeters of thickness in some places. Nearly 30 centimeters of it was composed of silt, clay and MO (Shepard, 1954). another layer was 10 to 15 centimeters thick and consisted of various clays encrusted with bivalve shells (Figure 8c). The third consisted of more than 40 centimeters of silt sediment, characteristic of a slow sedimentation (Luque et al., 2000). Bivalve shells separated two extreme events that did not allow this process to remain constant (López, 2003; Perez-Rojas et al., 2000), with radioactivity levels varying from place to place.

\section{Sedimentary Accumulation Rate and Mass Accumulation Rate}

From 1998-2011, a large amount of sediment was deposited in LE, notably elevating TAS and TAM. It should be noted that something similar happened to Lake Azuei in Haiti (Kushner, 2016), which also experienced a level rise (Wright et al., 2015). This study was centered on LE, where it was found that in the zone of influence of the rivers Guayabal and Las Barias from 2003-2011 deposited around $24 \mathrm{~cm}$ and $25 \mathrm{~cm}$, respectively, for a total TAS equal to almost $3.0 \mathrm{~cm} \mathrm{a}^{-1}$, while the TAM recorded $2.0 \mathrm{~g} \mathrm{~cm}^{-2} \mathrm{a}^{-1}$ for the same area. The calculated dates are only a few months away from the occurrence of the weather event. The bathymetry of the lake (Figure 6) changed slightly due to sedimentation, especially in the mouth of the main tributaries which showed the highest TAS levels recorded in that period. In the eastern part of the lake, as a result of the contributions of sediments removed by the waters in the Cristóbal canal (estimated at $5 \times 10^{6} \mathrm{~m}^{3}$, an MO content of around $15 \%$ was found.

Analysis of Variance (ANOVA) of the calculated dates was conducted; MAR and SAR with ${ }^{210} \mathrm{~Pb}$ in nine colors showing five years of extreme events that impacted the Lake Enriquillo region (see Fig. 7).

Table 4. The confidence intervals determined in the Analysis of Variance (ANOVA) show the date when, according to the calculations with ${ }^{210} \mathrm{~Pb}$ of the dates in nine colors indicating five episodes of growth of LE from extreme weather events, the influence of the extreme event on the sedimentation of the lake became evident. The upper row of the table corresponds to the date the phenomenon occurred: Hurricane Flora, 1963, Hurricane David, 1979, Hurricane George, 1998, Storm Odette, 2003, and Storms Olga-Noel, 2007. The Sedimentary and MAR calculated with $210 \mathrm{~Pb}$ show that these have been increasing, possibly associated with land use change, erosion, and deforestation.

Calculated date of sediment deposition

\begin{tabular}{llllll}
\hline Core & $\mathbf{2 0 0 7 . 9 2}$ & $\mathbf{2 0 0 3 . 9 7}$ & $\mathbf{1 9 9 8 . 8 1}$ & $\mathbf{1 9 7 9 . 7 5}$ & $\mathbf{1 9 6 3 . 8 4}$ \\
\hline No.2 & 2008.03 & 2004.17 & 1999.55 & 1979.85 & 1964.13 \\
No.4 & 2008.19 & 2004.28 & 1999.23 & 1980.55 & 1963.59 \\
No.6 & 2008.89 & 2004.45 & 1998.88 & 1979.94 & 1965.10 \\
No.8 & 2008.04 & 2004.41 & 1998.50 & 1980.45 & 1965.79 \\
No. 10 & 2008.06 & 2004.23 & 1999.49 & 1980.15 & 1965.89 \\
No. 13 & 2008.18 & 2004.13 & 1999.36 & 1980.68 & 1965.81 \\
No. 17 & 2008.48 & 2004.37 & 1998.95 & 1979.43 & 1967.03 \\
No.18 & 2008.23 & 2004.12 & 1998.68 & 1980.75 & 1967.52 \\
No. 20 & 2008.83 & 2004.09 & 1999.06 & 1979.76 & 1964.13 \\
\hline
\end{tabular}

Confidence Intervals for Group Means

\begin{tabular}{lllll}
\hline Group & Confidence Interval & & & \multicolumn{1}{c}{$\mathbf{~ - ~}$} \\
\hline 2008 & 2008.326 & \pm & 0.452963 & $95 \%$ \\
2004 & 2004.251 & \pm & 0.452963 & $95 \%$ \\
\hline
\end{tabular}




\begin{tabular}{|c|c|c|c|c|}
\hline 1998 & 1999.078 & \pm & 0.452963 & $95 \%$ \\
\hline 1980 & 1980.173 & \pm & 0.452963 & $95 \%$ \\
\hline 1965 & 1965.441 & \pm & 0.452963 & $95 \%$ \\
\hline Grand Mean & \multicolumn{4}{|c|}{1991.45} \\
\hline
\end{tabular}

Mass Accumulation Rate $\left(\right.$ MAR $\left.=\mathrm{gcm}^{-2} \mathbf{y}^{-1}\right)$

\begin{tabular}{llllll}
\hline Core & $\mathbf{2 0 0 7 . 9 2}$ & $\mathbf{2 0 0 3 . 9 7}$ & $\mathbf{1 9 9 8 . 8 1}$ & $\mathbf{1 9 7 9 . 7 5}$ & $\mathbf{1 9 6 3 . 8 4}$ \\
\hline No.2 & 6.652 & 2.244 & 1.025 & 0.933 & 0.368 \\
No.4 & 1.419 & 1.122 & 0.830 & 0.182 & 0.222 \\
No.6 & 0.988 & 1.724 & 1.026 & 0.435 & 0.252 \\
No.8 & 1.379 & 1.441 & 1.271 & 0.504 & 0.472 \\
No. 10 & 6.299 & 3.624 & 0.904 & 1.156 & 0.350 \\
No. 13 & 0.826 & 0.681 & 0.440 & 0.233 & 0.185 \\
No. 17 & 1.747 & 1.016 & 0.808 & 0.476 & 0.204 \\
No.18 & 0.624 & 1.086 & 1.672 & 0.500 & 0.217 \\
No. 20 & 0.797 & 2.490 & 1.267 & 0.202 & 0.195 \\
\hline
\end{tabular}

\section{Confidence Intervals for Group Means}

\begin{tabular}{|c|c|c|c|c|}
\hline Group & Confide & & & $1-$ \\
\hline 2008 & 2.30353 & \pm & 0.7876 & $95 \%$ \\
\hline 2004 & 1.71416 & \pm & 0.7876 & $95 \%$ \\
\hline 1998 & 1.02687 & \pm & 0.7876 & $95 \%$ \\
\hline 1980 & 0.51352 & \pm & 0.7876 & $95 \%$ \\
\hline 1965 & 0.27388 & \pm & 0.7876 & $95 \%$ \\
\hline Grand Mean & \multicolumn{3}{|c|}{1.16639} & \\
\hline
\end{tabular}

Sedimentary Accumulation Rate $\left(\mathrm{SAR}=\mathrm{cm} \mathrm{y}^{-1}\right)$

\begin{tabular}{llllll}
\hline Core & $\mathbf{2 0 0 7 . 9 2}$ & $\mathbf{2 0 0 3 . 9 7}$ & $\mathbf{1 9 9 8 . 8 1}$ & $\mathbf{1 9 7 9 . 7 5}$ & $\mathbf{1 9 6 3 . 8 4}$ \\
\hline No.2 & 3.226 & 1.168 & 0.730 & 0.791 & 0.312 \\
No.4 & 0.573 & 0.509 & 0.393 & 0.251 & 0.133 \\
No.6 & 3.086 & 1.753 & 1.237 & 0.604 & 0.357 \\
No.8 & 3.388 & 2.652 & 2.033 & 1.188 & 0.864 \\
No. 10 & 2.944 & 1.981 & 1.378 & 0.984 & 0.651 \\
No. 13 & 0.778 & 0.644 & 0.619 & 0.340 & 0.256 \\
No. 17 & 1.714 & 0.771 & 0.623 & 0.167 & 0.041 \\
No.18 & 0.489 & 0.560 & 0.304 & 0.183 & 0.115 \\
No. 20 & 1.505 & 1.281 & 0.799 & 0.374 & 0.147 \\
\hline
\end{tabular}

\section{Confidence Intervals for Group Means}

\begin{tabular}{llr}
\hline Group & Confidence Interval \\
\hline 2007.92 & 1.96701 & \\
2003.97 & 1.25772 & \\
1998.81 & 0.90175 & \\
1979.75 & 0.54256 & \\
1963.84 & 0.51156 & \\
\multicolumn{2}{l}{ Grand Mean } & 0.99772 \\
\hline
\end{tabular}

\section{Discussion of Results}

For the periods 1979-1992, 1993-1998, and 1999-2003, LE recorded severe droughts, its level dropping to 46 BSL. With the arrival of Hurricane David and Storm Frederic from August-September 1979, the lake spread 
approximately $291 \mathrm{~km}^{2}$ (NASA, 1982; Ducoudray, 2006). From 1979 to 2003, LE received less rainfall every year than it lost due to evaporation; as a result, its level decreased -42 BSL and the area dropped to $194.9 \mathrm{~km}^{2}$. The lake recovered slightly from droughts with Hurricane George in 1998. In December of 2003, its level began to rise with the arrival of the Odette storm, with recorded sediments data shown in profile 10 of between the $32-35 \mathrm{~cm}$ and similar to other profiles at other depths. In 1994, the salinity reached around $82 \%$ (Araguás-Araguás, 1993) and the lake occupied an area of $238.2 \mathrm{~km}^{2}$. In 2010 , the area had grown to $332.3 \mathrm{~km}^{2}$, with salinity dropping below $35 \%$ (Rosado et al., 2017).

The values of salinity in 1983 were $35 \%$ at the surface, similar to those of 2011 ; it is assumed that the same thing happened with the volume of water. The remaining rains of Hurricane David and Storm Frederic in 1979 served to maintain the level of Lake Enriquillo until 1982, when it began to decrease due to the low incidence of extreme weather events in the basin. This continued until Hurricane George in 1998 and the storm Odette in 2003. After the passage of Hurricane Tomas in 2010, the lake maintained its level without the occurrence of more powerful rainfall events until 2013, when levels began to rapidly decrease. The same pattern happened after the passage of Hurricane Flora in 1963 and Hurricane David and the storm Frederic in 1979, followed by heavy droughts. After completion of tritium measurements to measure the age of the water during the period of runoff in the Sierra de Neiba, it was confirmed that the rainwater falling in took between 2-3 years to reach the lake. It was estimated from bathymetric data that, between 1983 and 2010 , some $4.23 \times 10^{3} \mathrm{~m}^{3}$ of sediment was deposited, equivalent to a sea surface temperature SST of $1.0 \mathrm{~cm}$ per year, similar to that of profile 20 which originated from the northcentral part of the lake between Cabrito Island and The Sierra de Neiba. The same volume of water was received from 1983 to 2010 in the region, where water surface totals measured at 290 and $332.3 \mathrm{~km}^{2}$, respectively, (NASA, 2012 and The Guardian, 2012) for an increase of $42.3 \mathrm{~km}^{2}$ from the accumulation of sediments during the period. Similarly, researchers performed bathymetry and remote sensing analysis, reporting no fissures in the bottom of LE (Delanoy and Méndez-Tejeda, 2017; Mahrokh et al., 2017).

The area occupied after Hurricane David and Storm Frederic in 1979 was similar to the area occupied during 2009. Salinity is related to the dilution factor, so we assume that the amount of water in 2007 was similar to on May 2124, 2004, a stationary trough produced a sudden flood of the Río Blanco or Solié, which dragged rocks and mud through a neighborhood in the community of Jimaní, killing more than 400 people

The area the lake occupied after Hurricane David and Storm Frederic in 1979 was similar to the area occupied during 2009. Salinity is related to the dilution factor, so it is assumed that the amount of water in 2007 was similar. From May 21-24, 2004, a stationary trough produced a sudden flood of the Río Blanco or Solié, which dragged rocks and mud through a neighborhood in the community of Jimaní, killing more than 400 people. The town been established near the river bed, which at that time was dry (Cocco, 2009). Part of the material eroded and washed away to settle in Lake Enriquillo's southern section. That same year, Hurricane Jeanne impacted the basin, followed by Alpha Storm in 2005, Ernesto Storm (2006), Olga-Noel (2007), Gustav-Hanna-Ike (2008), Hurricane Tomas (2010), Hurricane Emily (2011), Storm Isaac (2012), and Hurricane Chantal in 2013 (Figure 7). After the passage of the Olga and Noel storms in 2007, the area occupied by the lake in 2008 reached $303 \mathrm{~km}^{2}$ and the level reached 36 BSL, as shown in Table 2 (SERVIR, 2009). The lake returned to cover the area it had occupied in 1979 in five years (2003-2008).

As of February 2011, salinity was recorded at $34 \%$ in most places measured, with exception to the main aquifers (Las Barias and Azufrada) and the lake's bottom (110\%). As shown in Table 2, these measurements were similar to those in 1983 (Margalef, 1985). The rains in 2012, plus what remained from 2010, caused the salinity for 2014 to fall to $23.4 \%$. As stated before, the arrival time for storm or hurricane water deposited in the lake through underground aquifers can take up to three years.

From 2003 to 2012, the LEB region, where precipitation is usually very low received enormous amounts of precipitation due to a series of extreme climatic events, primarily tropical storms and hurricanes (Figure 6), which led to flooding. The floods covered over $196.3 \mathrm{~km}^{2}$ of land, most which were being used for agriculture and livestock, and spread largely because of deforestation in the area (González et al., 2010).

By assuming constant flow, a Sedimentary Accumulation Rate (TAS) and a Mass Accumulation Rate (TAM) were determined to be very high over the last 100 years (Ruiz-Fernández, 2002) using lead $210\left({ }^{210} \mathrm{~Pb}\right)$ as the basis for radiological testing, with special attention given to the Guayabal sub-basin along the northern part of the lake. (Rozanski et al., 2004; Krishnaswami et al., 1971). Changes in TAS are associated with the occurrence of extreme weather events that affected the region (Brenner et al., 1988; López, 2003), as well as elemental distribution and mineralogy. The TAS and TAM (Figure 5 and Table 4) increased during extreme weather events (storms and hurricanes) and decrease with droughts. By comparing the ${ }^{210} \mathrm{~Pb}$ dating of the sediments (Brenner \& 
Bindford, 1988) and the OM content by ignition loss with the X-Ray Fluorescence technique of several sections (UNEP, 1998; Révész et al., 2012), variations in sediment type (Runnuw, 1999; Rudolph et al., 1984), as well as the elemental composition of the sediments (Loring et al., 1977), demonstrate a close relationship with extreme meteorological events (Figure 8).

\section{Conclusion}

The increase in LE's lake level, as well as surface occupation, in the DR began at the end of 2003, after the passing of the storm Odette. From 2003-2013, LE increased 13 meters by means of an increase in the rainfall in its basin, by the incidence of troughs, storms and hurricanes, and by the contribution of the river Yaque del Sur through the channel Cristóbal. Its salinity decreased from $105 \%$ in 2003 (Buck et al., 2005) to $23.4 \%$ in 2014. The composition of the sediments showed a change in the enrichment factors of several elements, normalized with calcium (Figure 8), indicating a change in climate when compared to strontium (Albert, 2008). Over the last 100 years, it has changed its level as a consequence of rainfall or drought seasons, changes that manifested in sediment diagenesis (Pantoja et al., 2010).

SAR and MAR have increased as a result of land use change and deforestation (Günter, 2003); their origin is from the Sierra de Neiba to the north and from Bahoruco to the south, the latter being lower by geomorphology (Winsor et al., 2012). According to the analysis of variance, extreme events have increased over time, causing a decrease in the water storage capacity of the lake and, therefore, a greater tendency to surface occupation. The bathymetry has changed slightly (1992-2013) due to the contributions of sediment from the various sub-basins by way of rain and not by seismic-tectonic factors.

Finally, an excellent article published by Moknatian et al 2017, tries to answer the question "Will Lake Azuei spill over into Lake Enriquillo? (it will not); what are the maximum attainable lake levels and what impact would it be if the lakes were to reach these maximum levels? " Although they answer that it is not possible due to the geological formations of the lakes, based on the bathymetric and remote sensing analyzes, we understand that the likelihood of the lakes uniting depends on the level of precipitation in the Lakes' region. Due to the fact that global warming contributes to the intensity of cyclonic systems generating more intense precipitations. Morris et al 2010.

Acknowledgments: To the Ministry of Higher Education Science and Technology (MESCyT) and the Autonomous University of Santo Domingo (UASD). To Dr. Plácido Gómez, MsC. Miledy Alberto, Dr. Carlos Rodríguez, Dr. Edith Paulino, Mr. Domingo Mercedes, Mr. Isabel Ulloa, Pedro Jiménez, José Osvaldo Suárez, Juan Pablo González, Benito Hernández Naut, Carlos Ramírez, Mónica Medina, Rafaelina Vargas, Omar Pérez Veloz, Ángela Luís Matos and Gabriel Ruiz.

\section{Reference}

Ahumada, R. (1991). Balance asimétrico del carbón orgánico particulado (COP), en la Bahía Concepción, Chile. Rev. Biol. Mar. Valparaíso, 26(2), 233-251.

Albert, J. (2008). Climate Change and Water Quality Issues. American Water Works Association Research Foundation. Drinking Water Research: Special Climate Issue, 18(2), 11-14.

Appleby, P. G., \& Oldfield, F., (1978). The calculation of lead-210 dates assuming a constant rate of supply of unsupported $210 \mathrm{~Pb}$ to the sediment Catena, $5,1-8$.

Araguás-Araguás, L., Michelen, C. \& Febrillet, J.,1993: Estudio de la dinámica del lago Enriquillo: Informe de avance. Internat. Atomic Energy Agency, Project DOM/8/006, Vienna, Austria.

Bionini, W. E., Hargraves, R. B., \& Shagan, R. (1984). The Caribean-South American Plate Boundary and Regional Tectonic. Geological Society of America, Memoir 162, USA.

Bird, J. M., \& Bassett, W. A., (1980). Evidence of a deep mantle history in terrestrial osmium-iridium-ruthenium alloys. Journal of Geophysical Research, B, 85(10), 5461-5470.

Bowin, C. (1966). Caribbean Gravity Field and Plate Tectonics. The Geological Society of America, Inc. Library of Congress Catalog Card Number 76-16261. I.S.B.N. 0-8137-2169-5.1966.

Brenner, M., \& Binford, M. W. (1988). A sedimentary record of human disturbance from Lake Miragoane, Haiti. J. Paleolimnol., 1, 85-97.

Buck, D., Brenner, D., Hodell, D., \& Curtis, J. (2003). La Historia Holocénica del Lago Enriquillo, República Dominicana: Un Lago de Hipersalinidad. Universidad de la Florida.

Buck, D., Brenner, M., Hodell, D., Curtis, J., \& Martin, J. (2005). Physical and chemical properties of hypersaline Lago Enriquillo, Dominican Republic. 
Cocco, A. (2009). El Ciclo Hidrológico del Lago Enriquillo y la Crecida extrema del 2009. Cuevas, L. 2013. Lago Enriquillo y Lago Sumatre. Dinámica de las inundaciones. Periodo, 2000-2013.

Comarazamy, D. E., González, J. E., Moshary, F., \& Plasecki, M. (2015). On the Hydrometeorological Changes of a Tropical Water Basin in the Caribbean and Its Sensitivity to Midterm Changes in Regional Climate. $J$. Hydrometeor, 16, 997-1013.

Cuevas, D. M., Sherman, C., Ramirez, W., \& Diaz, V. (July 2005). Development of the Mid-Holocene Cañada Honda Fossil Reef, Dominican Republic: Preliminary Results and Implications to Modern Trends of Reef Degradation in High Sedimentation Environments. In Proceeding of the Transactions 17th Caribbean Geological Conference, San Juan, Puerto Rico, 17-22.

Delanoy, Ramón, A., \& Méndez-Tejeda, (2017). Rafael Hydrodynamic Study of Lake Enriquillo in Dominican Republic. Journal of Geoscience and Environment Protection, 5, 115-124. Retrieved from $\mathrm{http}: / /$ www.scirp.org/journal/gep ISSN Online: 2327-4344 ISSN Print: 2327-4336

Díaz, De Neira, J. A., Solé, Y., \& Pont, F. J. (2002). Precisiones estratigráficas sobre el Neógeno de la cuenca de Azua (República Dominicana) Stratigraphic precisions about the Neogene of the Azua basin (Dominican Republic). Depto. de Geología. Informes y Proyectos S.A. (INYPSA). C/ Velazquez, 60. 28011 Madrid. Acta Geological Hispanica, 37(2-3), 163-181.

Dolan, J. F., \& Mann, P. (1998). Active Strike-Slip and Collisional Tectonics of the Northern Caribbean Plate Boundary Zone. Publication of The Geological Society of America, Special Paper $N^{\circ}, 326,174 \mathrm{p}$.

Dolan, J., Mann, P., De Zoeten, R., Heubeck, C., \& Shiroma, J. (1991). Sedimentologic, stratigraphicand tectonic synthesis of Eocene-Miocene sedimentary basins, Hispañiola and Puerto Rico. En: Geologic and tectonic development of the North America-Caribbean Plate boundary in Hispañiola. Geological Society of America Special Paper, 262.

Ducoudray, F. (2006). La Naturaleza Dominicana. Tomo 2. Región Sur. Colección Centenario. Grupo León Jimenes. Editora Corripio. ISBN de la obra completa 9945-422-05-7, Santo Domingo, Rep. Dominicana.

Gonzalez, J., Lin, L., Bouton, G., Walker, K., Molina, A. (2010). Growth of Lago Enriquillo, Final Report; Department of Environmental Engineering, Senior Design Project. The City College of New York. 140th Street: New York, NY, USA, 2010, 10031.

Greer, L., \& Swart, P. K. (2006), Decadal cyclicity of regional mid-Holocene precipitation: Evidence from Dominican coral proxies. Paleoceanography, 21, PA2020. https://doi.org/10.1029/2005PA001166.

Günter, G. (2003). Limnología de un Lago Tropical de Alta Montaña, en Ecuador: Características de los sedimentos y tasa de sedimentación. Revista de Biología Tropical. Print version ISSN 0034-7744. Rev. Biol Trop, 51(2), San José Jun. 2003. Costa Rica.

Hernaiz Huerta, P. P. (2004b). Mapa Geológico de la Hoja a E. 1:50.000 no 5871-I (La Descubierta) y Memoria correspondiente. Proyecto de Cartografía Geotemática de la República Dominicana. Programa SYSMIN. Dirección General de Minería, Santo Domingo.

Heubeck, C., \& Mann, P. (1991), Structural geology and cenozoic tectonic history of the southeastern termination of the Cordillera Central, Dominican Republic. En: Geologic and tectonic development of the North AmericaCaribbean Plate boundary in Hispañiola. Geological Society of America Special Paper, 262.

IAEA. (1989). Isotopes of Noble gases as tracers in environmental studies, Proceeding Consultants Meeeting, Vienna, 29 May-2 June 1989. Agency International Atomic Energy.

Krishnaswami, S., Lal, D., Martin, J., \& Meybeck, M. (1971). Geochronology of lake sediments. Earth and Planetary Science Letters, 11, 407-414

Kushner, J. (2016). The Relentless Rise of Two Caribbean Lakes Baffles Scientists In Haiti and the Dominican Republic, the lakes are flooding farmland, swallowing communities and leading to deforestation. National Geographic.

Lane, C. S., Hildebrandt, B., Kennedy, M. L., LeBlanc, A., Liu, K. B., Wgner, A. J., \& Hawkes, A. D. (2017). Verification of tropical cyclone deposits with oxygen isotope analyses of coeval ostracod valves. $J$. Paleolimnol, 57, 245-255. https://doi.org/10.1007/s10933-017-9943-5

López, C. L. (2003). Cambios Paleo ambientales en el noroeste Peninsular, durante el Holoceno, determinados a partir del Estudio de Foraminíferos Bentónicos. Universidad La Coruña, Facultad de Ciencias. España. 
Loring, D., \& Rantala, T. (1977). Geoquimical analyses of marine sediments and suspended particulate matter. Fisheries and Marine Service. Technical Report 700, p.44.

Luque, M., José, A., Julià, B., Ramón, (2016). El Lago de Sanabria: un sensor de las oscilaciones climáticas del Atlántico Norte durante los últimos 6.000 años El registro de la Pequeña Edad del Hielo (LIA), los eventos.

Mann P., Taylor, F. W., Burke, K., \& Kulstad, R. (1984). Subaerially exposed Holocene coral reef, Enriquillo Valley, Dominican Republic. Geol. Soc. America Bull., 95, 1084-1092. https://doi.org/10.1130/00167606(1984)95,1084:SEHCRE.2.0.CO;2.

Mann, P., Burke, K., \& Matumoto, T. (1984). Neotectonics of Hispañiola: plate motion, sedimentation, and seismicity at a restraining bend. Earth and Planetary Science Letters, 70, 311-324.

Mann, P., Draper, G., \& Lewis, J. F. (1991). Neotectonics of Hispañiola: Plate motion, sedimentation and seismicity at a restraining bend. Geological Society of America, Special Paper, 262.

Mann, P., McLaughlin, P. P., \& Cooper, C. (1991). Geology of the Azua and Enriquillo basins, Dominican Republic: 2, Structure and tectonics. En: Geologic and tectonic development of the North America-Caribbean Plate boundary in Hispañiola. Geological Society of America Special Paper, 262.

Mann, P., McLaughlin, P. P., van den Bold, W. A., Lawrence, S. R., \& Lamar, M. E. (1999). Tectonic and Eustatic Controls on Neogene Evaporitic and Siliciclastic Deposition in the Enriquillo Basin, Dominican Republic. In Caribbeans Basins, Sedimentary Basins of the World, 4(P. Mann Ed.), Elsevier Science B. V., Amsterdam, 287-342.

Marcano, E. (1987). Flórula de la Isla Cabritos. UASD. Santo Domingo, Rep. Dominicana.

Margalef, R. (1985). Limnología del Lago Enriquillo (República Dominicana). Ed. Universitat de Baracelona. Spain ISBN 978-84-475-37-47-1

Medley, P., Tibert, E. N., Patterson, W. P., Currran, A. H., Greer, L., Colin, J. P. (2017). Paleosalinity history of middle Holocene lagoon and lacustrine deposits in the Enriquillo Valley, Dominican Republic based on pore morphometrics and isotope geochemistry of Ostracoda. Micropaleontology, 53, 409-419.

Méndez-Tejeda, R., Rosad, G., Rivas, D. V., Montilla, T., Hernández, S., Ortiz, A., \& Santos, F. (2017). Climate Variability and Its Effects on the Increased Level of Lake Enriquillo in the Dominican Republic, 2000-2013. http://pubs.sciepub.com/aees/4/1/4/. Applied Ecology and Environmental Sciences, 4(1), 26-36. https://doi.org/10.12691/aees-4-1-4

Meyers P. A., \& Teranes, Y. J. L. (2001). Sediment organic matter. En: W. Last W. Y J. P. Smol (Eds.). Tracking environmental change using lake sediments. Kluwer Academic Publishers. Holanda.

Meyers, P. A., \& Ishiwatari, Y. R. (1993). Lacustrine organic geochemistry-an overview of indicators of organic matter sources and diagénesis in lake sediments. Orgaic Geochemestry, 20, 867-900.

Moknatian, M., Piasecki, M., \& González, J. (2017). Development of Geospatial and Temporal Characteristics for Hispaniola's Lake Azuei and Enriquillo Using Landsat Imagery. Remote Sens., 9(6), 510. https://doi.org/10.3390/rs9060510.

Morris, A. Bender, Thomas, R., Knutson, Robert, E., Tuleya, Joseph, J., Sirutis, Gabriel, A., Vecchi, Stephen, Garner, T., \& Isaac, M. H. (2010). Modeled Impact of Anthropogenic Warming on the Frequency of Intense Atlantic Hurricanes. Science, 327(5964), 454-458. https://doi.org/10.1126/science.1180568

Mosqueda, P., Fernando, Vaca, G., Federico, Villa, A., \& Maria (2010). Desarrollo de procedimientos para la determinación de radioisótopos en muestras ambientales mediante técnicas de bajo recuento por centelleo líquido y radiación Cerenkov, Universidad de Huelva. Tesis Doctoral. ISBN: 978-84-2944-47-7, D.L.: H 2512010.

NASA (1982, 2003, $2008 \quad \& \quad 2012) . \quad$ Retrieved May 27, 2017, from https://www.nasa.gov/topics/earth/features/ess20_societal_irwin.html

NOAA. (accessed on 24 May 2017) . Retrieved from http://www.nhc.noaa.gov/data/

Páez-Osuna. F., Fong-Lee., M., \& Fernández-Pérez, H. (1984). Comparación de tres técnicas para analizar materia orgánica en sedimentos. Instituto Ciencia del Mar y Limnología. Universidad Nacional Autónoma de México. México DF, 60-75.

Pantoja, S., Hughen, K., González, F., Sepúlveda, J., Lange, C., Rossel, P., Lorca, G., Muñoz, P., Salamanca, M., \& Ávila, A. (2010). Registros de Alta Resolución de Cambios Climáticos y Diagénesis en Sedimentos de 
rápida depositación de los Fiordos Chilenos. Universidad de Concepción, Concepción, Chile Woods Hole Oceanographic Institution, Woods Hole, Usa. 2010.

Pérez-Rojas, A., Torres-Orozco, H. B., Morales-Gutierrez, E., \& Pérez-Mendez, Y. E. (2000). Textura, composición y contenido de materia orgánica de los sedimentos de un lago tropical de México. Hidrobiológica, 10(1), 4150 .

Pubellier, M., Mauffret, A., Leroy, S., Vila, J. M., \& Amilcar, H. (2000). Plate boundary readjustment in oblique convergence: Example of the Neogene of Hispaniola, Greater Antilles. Tectonics 19. ISSN: 0278-7407. https://doi.org/10.1029/2000TC900007

Radke, L. C., Smith, C. S., Ryan, D. A., Brooke, B., \& Heggie, Y. D. (2003). Coastal Indicator Knowledge and Information System I: Biophysical Indicators. Canberra: Geoscience Australia. Retrieved from http://www.ozestuaries.org/indicators.

Révész, Kinga, Buck, Bryan, \& Coplen, T. B. (2012). Determination of the $\delta 2 \mathrm{H}$ and $\delta 18 \mathrm{O}$ of soil water and water in plant matter; RSIL lab code1700, chap. 19 of Stable isotope-ratio methods, U.S. Geological Survey Techniques and Methods, book 10, p.21. Retrieved from http://pubs.usgs.gov/tm/10c19/

Rodríguez, A., \& Jiménez, G. A. (1996). Separación del 210Pb, 210Bi y 210Po mediante columna de cambio iónico y su calibración por centelleo líquido, CIEMAT.

Romero-Luna, E. J., \& Poteau, D. (2011). Water Level Fluctuations of Lake Enriquillo and Lake Saumatre in Response to Environmental, C. (2011). A Masters of Engineering Project Presented to the Faculty of the Graduate School of Cornell University: Ithaca, NY, USA.

Rosado, G., Rafael, M. T., Rivas, V. D., \& Infante I. M. (2016). Physicochemical analysis of Lake Enriquillo in Dominican Republic. Open Science Journal, 1(3). Retrieved from https://osjournal.org/ojs/index.php/OSJ/article/view/638/44

Rozanski, Kazimierz; Gonfiantini, Roberto. 2004. Isótopos en estudios climatológicos. Boletín OIEA 4/1990.

Rudolph, A., Ahumada, R., \& Hernández, S. (1984). Distribución de la materia orgánica, carbono orgánico, nitrógeno orgánico y fósforo total en los sedimentos recientes de la Bahía Concepción. Biología Pesquera,13, 71-82.

Ruiz-Fernández, A. C., F. Páez-Osuna, M. L. Machain-Castillo, Y. E., \& Arellano-Torres (2004). 210Pb geochronology and trace metal fluxes $(\mathrm{Cd}, \mathrm{Cu}$ and $\mathrm{Pb})$ in the Gulf of Tehuantepec, South Pacific of Mexico. Journal of Environmental Radioactivity, 76, 161-175.

Ruiz-Fernández, A. C., Hillaire-Marcel, C., Ghaleb, B., Soto-Jiménez, M., \& Páez-Osuna., Y. F. (2002). Recent sedimentary history of anthropogenic impacts on the Culiacan River Estuary, Northwestern Mexico: Geochemical evidence from organic matter and nutrients. Environmental Pollution, 188, 365-377.

Runnuw, R. (1999). Minerals and mineraloids in marine sediments. An optical identification guide. Elsevier, Nueva York. 279 p.

Sánchez-Cabeza, J. A., \& Ruiz-Fernández, A. C. (2012). 210Pb sediment radiochronology: An integrated formulation and classification of dating models, Institut de Ciencia i Tecnologia Ambientals, and Department de Física, Universitat Autonoma Barcelona, Spain, Instituto de Ciencias del Mar y Limnolog? Universidad Nacional Autónoma de México, México.

SERVIR. (2009). Retrieved from http://www.servir.net/servir-en-accion/analisis-de-desastres/236-inundacionesen-lago-enriquillo,-republica-dominicana---marzo-2009.html

Shepard, F. P. (1954). Nomenclature based on sand-sill-clay ratios. Journal of Sedimenary Petrology, 24, 151-158.

Stemann, T. A., \& Johnson, K. G. (1992). Coral assemblages, biofacies, and ecological zones in the mid-Holocene reef deposits of the Enriquillo Valley, Dominican Republic. Lethaia, 25(3), 231-241.

The Guardian. Rapidly Rising Lake Levels Threaten Trade on Dominican-Haiti Border. 2012. Retrieved from http://www.TheGuardian.com

Trefethen, J. M., (1981). Geología para Ingenieros. Décima edición, Cia. Editorial Continental, s.a. México.

UNEP/IOC/IAEA. (1995). Manual for the geochemical analysis of marine Sediments and suspended particulate matter. Reference methods for Marine Pollution Studies No. 63. United Nations Environment Programme, 74 pp. Loring, D. H., \& Rantala R. T. T. (1992). Manual for the geochemical analyses of marine sediments and suspended particulate matter. Earth-Science Reviews, 32, 235-283. 
USGS (2010). Retrieved from https://www.usgs.gov/news/earthview-\%E2\%80\%93-lake-levels-hispaniola-risedramatically

Van den Berghe, B. (1983). Evolution sédimentaire et structurale depuis le paléocène du secteur "Massif de la Selle-Bahoruco-Nord de la ride de Beata" dans l'orogène nord-Caraibe: Paris, France, Université Pierre et Marie Curie, p.205

Wallace, M. H. (1947). A review of the stratigaphy of the Enrriquillo basin, Dominican Republic, Unpublished reports, Dominican Seaboard Oil Company, 12p.

Winsor, K., Allen, C. H., Greer, L., \& Glumac, B. (2012). Unusual Holocene Serpulid-Tufa Bioherms, Enriquillo Valley, Dominican Republic: Morphologies And Paleoenvironmental Implications. PALAIOS, 27, 693-706. https://doi.org/10.2110/palo.2011.p11-118r

Wright, V.D., Hornbach, M.J., Mchugh, C. and Mann, P. (2015) Factors Contributing to the 2005- Present, Rapid Rise in Lake Levels, Dominican Republic and Haiti (Hispaniola). Natural Resources, 2015, 6, 465-481 Published Online August 2015 in SciRes. https://doi.org/10.4236/nr.2015.68045

\section{Copyrights}

Copyright for this article is retained by the author(s), with first publication rights granted to the journal.

This is an open-access article distributed under the terms and conditions of the Creative Commons Attribution license (http://creativecommons.org/licenses/by/4.0/). 